\title{
Biochemical profile of coconut water from coconut palms planted in an inland region
}

\author{
Renata Vigliar, ${ }^{1}$ Vera L. Sdepanian, ${ }^{2}$ Ulysses Fagundes-Neto ${ }^{3}$
}

\begin{abstract}
Objective: To analyze the biochemical profile of coconut water from dwarf coconut palms planted in non-coastal regions, during the maturation period (sixth to ninth month).

Methods: Eight of 15 coconut palms planted in a non-coastal region were selected by lots and their coconuts sent to a laboratory for extraction and analysis of the coconut water. Coconut water from a total of 45 coconuts, from the sixth to ninth months' maturity, were analyzed to measure glucose, electrolytes, total proteins and osmolarity and to identify the sugars contained.

Results: The analysis of coconut water from the sixth to ninth month did not find any differences in the median concentrations of sodium ( $3 \mathrm{mEq} / \mathrm{L} ; 2$ and 3 ), glucose $(0.6 \mathrm{~g} / \mathrm{L} ; 0.3$ and 17.3$)$ or total proteins $(9 \mathrm{~g} / \mathrm{L} ; 6$ and 12$)$, but detected a reduction in the concentration of potassium $(64 \mathrm{mEq} / \mathrm{L} ; 46$ and 99$)$, calcium $(6.5 \mathrm{mmol} / \mathrm{L} ; 5$ and 8.5$)$, magnesium ( $8 \mathrm{mmol} / \mathrm{L} ; 3.9$ and 9.8$)$, chloride $(38.5 \mathrm{mEq} / \mathrm{L} ; 30$ and 48.7$)$ and osmolarity $(419 \mathrm{mOsmol} / \mathrm{L} ; 354$ and 472 ). With relation to the sugars, identified by chromatography on paper, an increase was observed from the sixth to the ninth month in the concentration of fructose $(68 \mathrm{mg} / \mu \mathrm{L} ; 44$ and 320$)$ and glucose $(299 \mathrm{mg} / \mu \mathrm{L} ; 262$ and 332$)$ and in conjunction with a concentration of sucrose ( $340 \mathrm{mg} / \mu \mathrm{L} ; 264$ and 390$)$.

Conclusions: The biochemical profile of coconut water varied as the coconuts matured, observing reductions in the concentration of potassium, calcium, magnesium, chloride and osmolarity. Descending paper chromatography revealed an increase in the concentration of fructose and glucose and also a reduction in the concentration of sucrose.

J Pediatr (Rio J). 2006;82(4):308-12: Cocos, electrolytes, glucose, carbohydrates, osmolarity, oral rehydration therapy.
\end{abstract}

\section{Introduction}

The coconut palm is considered the tree of life, since it is one humanity's principal vegetable resources. Every part of this plant can be utilized: roots, husk, leaves, inflorescence and fruit. ${ }^{1}$ The fruit of the dwarf coconut palm, particularly the green dwarf coconut palm, are cultivated for their liquid content, whereas the fruit of the giant coconut palm and the hybrids are cultivated for their albumin, which can be used au naturelle or processed into grated dried solids or coconut milk. ${ }^{2}$ Flavor varies depending on the stage of maturation of the fruit.

1. Mestre em Ciências, Departamento de Pediatria, Escola Paulista de Medicina, Universidade Federal de São Paulo (UNIFESP), São Paulo, SP, Brasil.

2. Professora adjunta, Doutora, Departamento de Pediatria, UNIFESP, São Paulo, SP, Brasil.

3. Professor titular, Departamento de Pediatria, UNIFESP, São Paulo, SP, Brasil.

Manuscript received Oct 10 2005, accepted for publication Apr 052006.

Suggested citation: Vigliar R, Sdepanian VL, Fagundes-Neto U. Biochemical profile of coconut water from coconut palms planted in an inland region. J Pediatr (Rio J). 2006;82:308-12.
Coconut water is the juice of the endosperm found within the cavity of the coconut, which begin to form around 2 months after the natural opening of the inflorescence. According to research, coconut water accounts for $25 \%$ of the weight of the fruit, and its basic composition is $95.5 \%$ water, $4 \%$ carbohydrates, $0.1 \%$ fat, $0.02 \%$ calcium, $0.01 \%$ phosphorous, $0.5 \%$ iron, in addition to amino acids, vitamin C, B complex vitamins and mineral salts. ${ }^{1}$

In some countries coconut water is used as a solution for oral hydration, as part of the daily diet and as a protein supplement when nutritional deficits are intense. During the Second World War, coconut water was even used instead of saline solution during emergency surgeries. ${ }^{1}$

Some studies suggested that coconut water can be used for intravenous rehydration. ${ }^{3,4}$ Other studies suggest that coconut water can be used for electrolyte replacement in a wide range of situations. ${ }^{5-7}$ Studies have compared the chemical composition of coconut water with teas, ${ }^{8}$ still soft drinks, ${ }^{7}$ carbonated soft drinks, ${ }^{7,8}$ isotonic drinks ${ }^{9}$ and oral rehydration solution (ORS). 10 
There are a small number of studies that have related the composition of coconut water to the stage of maturation of the coconut 6,11 or with the region where the coconut palms grow (coastal or inland). 6,12

We therefore decided to carry out the current study with the following objectives: to analyze the biochemical profile of coconut water from dwarf coconut palms planted in inland areas at different stages of maturation of the coconuts, from the sixth to the ninth months; to determine the concentrations of sodium, potassium, chloride, calcium, magnesium, glucose, total proteins and osmolarity of coconut water from the sixth to the ninth months; to identify the sugars contained in coconut water from the from the sixth to the ninth months.

\section{Methods}

This was a cross-sectional study analyzing coconut water from coconut palms in inland regions. Eight of the fifteen coconut palms growing at the Lagoa Azul farm, which is on the banks of the River Araguaia, in the municipality of Britânia, (Goiás state, Midwest Region, Brazil) were chosen for the study by lots. At least one coconut from each palm was to be analyzed at different stages of maturity from the sixth to the ninth months. As a result of climactic issues in the Midwest Region of Brazil, the maximum number of coconuts obtained at eight and nine months was four and five, respectively. The coconuts were air freighted to the laboratory, arriving a maximum of 24 hours after being harvested. Immediately upon arrival at the laboratory they were perforated and the fluid collected for analysis.

Concentrations of the following electrolytes were assayed: sodium, potassium, chloride, calcium and magnesium. The concentrations of glucose and total proteins were also determined, together with the osmolarity of the coconut water. Sodium and potassium were assayed by flame photometry, ${ }^{13}$ and chloride was determined by the Schales \& Schales titrimetric method. ${ }^{14,15}$ Glucose assays were by enzymatic reaction with glucose oxidase and peroxidase; ${ }^{15-17}$ calcium was measured by the o-cresolphthalein complexone method; 15,18 magnesium, by the magnon-sulphonade method 15,19 and total proteins with biuret reagent, 15,20 and in all cases analysis was performed by spectrophotometry. Osmolarity was measured with a freezing point osmometer. ${ }^{13}$ We employed descending paper chromatography 21,22 to identify the following sugars: fructose, glucose, sucrose and galactose.

The comparison between different months of maturity was made using the Kruskal-Wallis test, complemented by Dunn's multiple comparison test using Jandel Sigma Stat software. 23
Significance was defined at less than $5 \%$. The study was approved by the Research Ethics Committee at the Universidade Federal de São Paulo - Escola Paulista de Medicina.

\section{Results}

Table 1 lists median values (with 25th and 75th percentiles) for the study parameters and also the level of significance of statistical differences, ${ }^{23}$ broken down by maturity.

Increases were observed in the median volume of coconut water, the weight of the coconut shells and the total weight of the coconuts, as they matured. Thus, the more mature the coconut, the greater the volume of coconut water, the heavier the shell and the heavier the total weight.

The analysis of electrolytes did not reveal any difference in the median (with 25 th and 75 th percentiles) sodium concentration ( $3 \mathrm{mEq} / \mathrm{L} ; 2$ and 3 ) of the coconut water as the coconuts matured, and it should also be pointed out that these concentrations were low throughout the study period. Differences were observed in the median concentration of potassium ( $64 \mathrm{mEq} / \mathrm{L} ; 46$ and 99), calcium (6.5 mmol/L; 5 and 8.5), magnesium ( $8 \mathrm{mmol} / \mathrm{L} ; 3.9$ and 9.8 ) and chloride (38.5 mEq/L; 30 and 48.7$)$ in the coconut water. The concentration of these electrolytes dropped from the sixth to the ninth month of maturation, and the elevated concentration of potassium during all months stood out.

An increase was observed in the median (with 25th and 75th percentiles) glucose concentration of coconut water $(0.6 \mathrm{~g} / \mathrm{L} ; 0.3$ and 17.3$)$ from the sixth to the ninth month of maturation, and there were no differences between the median concentrations of total proteins $(9 \mathrm{~g} / \mathrm{L} ; 6$ and 12) for the months studied. The median osmolarity of the coconut water (419 mOsmol/L; 354 and 472) was observed to reduce from the sixth to the ninth month of maturation.

With relation to the sugars identified by descending paper chromatography, the presence of fructose, glucose and sucrose were all detected in the coconut water. An increase was observed in the median concentration of fructose ( $68 \mathrm{mg} / \mu \mathrm{L} ; 44$ and 320 ) and glucose $(299 \mathrm{mg} / \mu \mathrm{L}$; 262 and 332) as the months passed, while sucrose concentration ( $340 \mathrm{mg} / \mu \mathrm{L} ; 264$ and 390 ) reduced between the sixth and ninth months of maturation of the coconut.

\section{Discussion}

Coconut water is often used as an alternative solution for oral rehydration, particularly in regions where mothers' knowledge of oral rehydration is lacking, thus avoiding incorrect preparation of sugar-salt solutions. 24,25 
Table 1 - Median values (with 25th and 75th percentiles) for each of the parameters investigated, broken down by coconut maturity

\begin{tabular}{|c|c|c|c|c|c|c|c|c|c|c|}
\hline & \multicolumn{8}{|c|}{ Maturity in number of months } & \multirow[t]{3}{*}{$\mathbf{p}$} & \multirow{3}{*}{$\begin{array}{c}\text { Comparisons } \\
\text { between } \\
\text { months } \\
\text { where } \\
\text { p }<0.05^{+}\end{array}$} \\
\hline & \multicolumn{2}{|c|}{$6(n=18)$} & \multicolumn{2}{|c|}{$7(n=18)$} & \multicolumn{2}{|c|}{$9(n=4)$} & \multicolumn{2}{|c|}{$9(n=5)$} & & \\
\hline & Median & $25-75$ & Median & $25-75$ & Median & $25-75$ & Median & $25-75$ & & \\
\hline Total weight $(\mathrm{g})^{*}$ & 526 & $486-478$ & 627 & $442-984$ & 1173 & $761-1586$ & 1627 & $1214-1956$ & 0.053 & \\
\hline Weight of shell $(\mathrm{g})^{\dagger}$ & 407 & $363-535$ & 527 & $393-777$ & 898 & $635-1212$ & 1203 & $962-1556$ & 0.016 & $6 \times 9$ \\
\hline Volume $(\mathrm{ml})^{*}$ & 55 & $30-110$ & 80 & $19-370$ & 272 & $130-365$ & 325 & $225-380$ & 0.061 & \\
\hline Sodium $(\mathrm{mEq} / \mathrm{L}) *$ & 2.5 & $2.0-3.0$ & 2.5 & $2.0-3.0$ & 3.5 & $2.5-5.5$ & 2 & $1.8-3.2$ & 0.618 & \\
\hline Potassium $(\mathrm{mEq} / \mathrm{L})^{\dagger}$ & 100 & $80-125$ & 51 & $43-65$ & 40 & $37-44$ & 49 & $44-69$ & $<0.001$ & $6 \times 9$ \\
\hline Chloride $(\mathrm{mEq} / \mathrm{L})^{\dagger}$ & 47 & $40-58$ & 31 & $25-43$ & 38 & $30-39$ & 30 & $24-34$ & $<0.001$ & $6 \times 9$ \\
\hline Calcium $(\mathrm{mmol} / \mathrm{L})^{+}$ & 5.3 & $4.4-7.2$ & 8.1 & $6.5-10.6$ & 7 & $5.6-9.4$ & 4.6 & $2.8-5.4$ & 0.003 & $6 \times 7 ; 7 \times 9$ \\
\hline Magnesium $(\mathrm{mmol} / \mathrm{L})^{\dagger}$ & 9.8 & $9.2-10.3$ & 5.6 & $4.3-9.3$ & 3.4 & $3.2-4.1$ & 3.4 & $2.1-4.3$ & $<0.001$ & $\begin{array}{c}6 \times 7 ; 6 \times 8 \\
6 \times 9\end{array}$ \\
\hline Glucose $(\mathrm{g} / \mathrm{L})^{*}$ & 0.4 & $0.2-2.3$ & 0.9 & $0.3-18.0$ & 13.5 & $4.6-19.0$ & 16.5 & $12.1-17.9$ & 0.097 & \\
\hline Proteins $(\mathrm{g} / \mathrm{L})^{*}$ & 9.5 & $8.0-15.0$ & 9 & $5.0-12.0$ & 5.5 & $4.0-10.5$ & 6 & $6.0-7.5$ & 0.118 & \\
\hline Osmolarity $(\mathrm{mOsm} / \mathrm{L})^{\dagger}$ & 452 & $385-485$ & 421 & $358-470$ & 282 & $205-346$ & 406 & $358-423$ & 0.037 & $6 \times 8$ \\
\hline
\end{tabular}

* Kruskal-Wallis test.

† Multiple comparison tests (Dunn's method).

The majority of studies that analyzed the composition of coconut water did not mention the location where the trees were planted, ${ }^{3-5,7-10}$ although some did state that they studied coastal coconuts $6,11,12$ and a single study analyzed inland coconuts. ${ }^{12}$

The median sodium concentration observed in coconut water in this study was very similar to all of the previouslypublished research, ${ }^{3-6,8-12}$ varying from 0.4 to $14.8 \mathrm{mEq} / \mathrm{L}$, with the exception of one study that found an elevated mean sodium concentration $(32.5 \mathrm{mEq} / \mathrm{L}) .{ }^{7}$ Comparing the composition of the ORS recommended by the World Health Organization (WHO) ${ }^{26}$ (Table 2) with the results of studies that have analyzed coconut water, it will be observed that the sodium concentration in the coconut water is far below that in the ORS and that, in the results from the current study, the figure is practically 30 times lower (Table 2).

Since the first study of the chemical composition of coconut water, the mean observed potassium concentration has always been above $30.0 \mathrm{mEq} / \mathrm{L}$. There was no difference between the potassium concentration of coconut water from coastal and inland palms, nor between more and less mature coconuts. ${ }^{6,11}$ No significant difference was observed between the potassium concentration of the coconut water studied here and the results of other studies, irrespective of whether they used coastal or inland coconuts. In the results of the current study, in common with those of the others, potassium concentration was above that in rehydration oral salts $(20 \mathrm{mmol} / \mathrm{L})$ (Table 2$)$.
On the other hand, both in this study and in other publications, the chloride concentration was below that recommended by the WHO for ORS, with a decline in observed concentrations during the present study from the sixth to the ninth month of maturation of the coconut.

The glucose concentration of coconut water varies $(0.01$ to $40.3 \mathrm{~g} / \mathrm{L})$ in studies that analyzed coconuts from inland and coastal regions. In the current study the concentration of glucose was below what is recommended for ORS by the WHO at all different stages of maturation of the coconuts (Table 2).

We found that this study and all the others recorded coconut water osmolarity values above $280 \mathrm{mOsm} / \mathrm{L}$. Comparing the osmolarity of coconut water and the WHO ORS, we observe that the majority of studies published figures above the recommended level - including the current study.

Currently the WHO recommends a reduced ORS, with lower concentrations of glucose and sodium and, consequently, lower osmolarity 27 (Table 2). When we compared the coconut water studied here with that solution, we observed that the potassium concentration is at least twice that of the reduced ORS, while the sodium concentration is at best 18 times less than the recommended level. With relation to chloride, concentrations were lower than in the reduced ORS, in particular from the seventh to the ninth months, at around half that recommended by the WHO. The concentration of glucose reached levels close to that in the reduced ORS by the eighth and ninth months 
Table 2 - Results for electrolytes and glucose concentrations and osmolarity of coconut water from coconuts at varying stages of maturity, as observed by this study and as published by others, together with the composition of the World Health Organization oral rehydration solution

\begin{tabular}{|c|c|c|c|c|c|c|c|c|}
\hline Authors & Maturity & $\begin{array}{l}\text { Sodium } \\
\text { mEq/L }\end{array}$ & $\begin{array}{c}\text { Potassium } \\
\text { mEq/L }\end{array}$ & $\begin{array}{l}\text { Chloride } \\
\text { mEq/L }\end{array}$ & $\begin{array}{l}\text { Calcium } \\
\text { mmol/L }\end{array}$ & $\begin{array}{c}\text { Magnesium } \\
\text { mmol/L }\end{array}$ & $\begin{array}{c}\text { Glucose } \\
\text { g/L }\end{array}$ & $\begin{array}{c}\text { Osm } \\
\text { mOsm/L }\end{array}$ \\
\hline \multirow[t]{4}{*}{ Vigliar et al. } & $6 \mathrm{~m}$ & 3 & 98 & 48.7 & 6 & 9.4 & 2.9 & 422.7 \\
\hline & $7 \mathrm{~m}$ & 3.1 & 62.1 & 36.3 & 8.6 & 6.4 & 9.2 & 419.6 \\
\hline & $8 \mathrm{~m}$ & 4 & 40.2 & 34.4 & 7.5 & 3.6 & 11.8 & 275.8 \\
\hline & $9 \mathrm{~m}$ & 2.4 & 57.2 & 28.8 & 4.4 & 3.4 & 14.2 & 395.4 \\
\hline \multirow[t]{6}{*}{ Kuberski et al. ${ }^{6}$} & $5 \mathrm{~m}$ & 1.1 & 44.8 & - & 4.8 & 5.5 & 22.3 & - \\
\hline & $6 \mathrm{~m}$ & 0.4 & 45.1 & - & 4.9 & 5.4 & 22.1 & - \\
\hline & $7 \mathrm{~m}$ & 2 & 54.3 & - & 5.2 & 4.7 & 24.8 & - \\
\hline & $8 \mathrm{~m}$ & 2.5 & 51.9 & - & 5.4 & 5 & 23.9 & - \\
\hline & $9 \mathrm{~m}$ & 5.8 & 53.8 & - & 5.9 & 5.2 & 21.4 & - \\
\hline & $10 \mathrm{~m}$ & 6.9 & 51.5 & - & 5.8 & 5.4 & 7.6 & - \\
\hline \multirow[t]{2}{*}{ Msengi et al.12 } & $\pm 7-8 \mathrm{~m}$ & 0.5 & 82 & 38.3 & 3.7 & 14.4 & 28.6 & - \\
\hline & $\pm 7-8 \mathrm{~m}$ & 0.8 & 82 & 38.8 & 3.6 & 12.4 & 27.5 & - \\
\hline \multirow[t]{8}{*}{ Fagundes Neto et al. ${ }^{11}$} & $5 \mathrm{~m}$ & 2.9 & 64.9 & 44.8 & 4 & 1.7 & 25.9 & 362.9 \\
\hline & $6 \mathrm{~m}$ & 1.3 & 61.7 & 43.7 & 3 & 1.5 & 37.3 & 372.7 \\
\hline & $7 \mathrm{~m}$ & 5 & 66.9 & 48.4 & 3.2 & 1.9 & 40.3 & 402.4 \\
\hline & $8 \mathrm{~m}$ & 11.2 & 65.8 & 50.4 & 3.2 & 1.8 & 33.9 & 384.7 \\
\hline & $9 \mathrm{~m}$ & 14.8 & 54.9 & 41.2 & 2.6 & 2 & 22.1 & 336.8 \\
\hline & $10 \mathrm{~m}$ & 12.6 & 54.2 & 37.1 & 3.6 & 2.3 & 10.8 & 325.9 \\
\hline & $11 \mathrm{~m}$ & 13.6 & 54.2 & 19.4 & 3.7 & 2.6 & 2.7 & 319.7 \\
\hline & $12 \mathrm{~m}$ & 13 & 42.7 & 39.7 & 3.2 & 1.8 & 0.4 & 290.3 \\
\hline ORS-WHO 26 & - & 90 & 20 & 80 & - & - & 20 & 311 \\
\hline Reduced-ORS-WHO 27 & - & 75 & 20 & 65 & - & - & 13.5 & 245 \\
\hline
\end{tabular}

ORS $=$ oral rehydration solution; Osm = osmolarity; WHO = World Health Organization.

of maturation. The osmolarity of the coconut was almost double that of the reduced ORS, with the exception of the eighth month.

In a Brazilian study that analyzed coconut water from a coastal region at different stages of coconut maturation, 11 some components of the coconut water varied considerably. Osmolarity in that study was above $300 \mathrm{mOsm} / \mathrm{L}$ throughout (probably because of the high concentrations of carbohydrates), and this study also observed similar levels. The glucose concentration in that study passed $200 \mathrm{mmol} / \mathrm{L}(35 \mathrm{~g} / \mathrm{L})$, whereas in this study the maximum level observed was $79 \mathrm{mmol} / \mathrm{L}(14 \mathrm{~g} / \mathrm{L})$. Sodium concentration was low throughout the maturation process, also confirmed here. The differences may be the result of the location of cultivation, in the study by Fagundes Neto the palms were at the coast and in this study they are planted inland.

Research by Kuberski ${ }^{6}$ identified the sugars contained in coconut water, detecting glucose, sucrose and fructose in the proportion of approximately 50, 35 and 15\%, respectively, but their study did not relate whether these proportions remained constant during different months. The current study found that the proportions of these sugars varied depending on the stage of maturation of the coconuts: glucose, from 34 to $45 \%$; sucrose, from 53 to $18 \%$ and; fructose, from 12 to $36 \%$.

The majority of studies did not analyze trace elements such as calcium and magnesium. The concentration of these trace elements did not exceed $17 \mathrm{mmol} / \mathrm{L}$ in the coconut water studied by many of the authors mentioned, $3,6,7,11,12$ in common with this study. Taking into account reference daily nutrient intakes, ${ }^{28}$ according to age group and calcium and magnesium concentrations during the seventh month, it is possible that nutritional deficiencies of these trace elements could be prevented by the daily ingestion of coconut water.

Before ending, we emphasize that the results of this study should be analyzed and interpreted with prudence, taking account of the possible limiting effect of the lower number of coconuts analyzed at months eight and nine. This was the result of climactic conditions in the Midwest Region of Brazil, where it did not prove possible to obtain 
a larger number of coconut water samples during those two months. On the subject of the total number of green coconuts analyzed to construct a biochemical profile of coconut water, four $5,6,8,10$ of the seven $3,5,6,8,10$-12 studies that mentioned the number of coconuts analyzed, the median (percentiles 25 and 75 in parenthesis) was eight (5.5-32.5) coconuts. It should be pointed out that the only study in the literature that employed coconuts from inland areas used 25 of them, but that study did not analyze them at different stages of maturity. On the other hand, the present study analyzed a total of 45 coconuts, which were studied at different stages of the maturation process, and it was factors related to the climate that barred the investigation of a larger number of coconuts during the last months of maturation. Further studies should be carried out to better characterize the biochemical profile of the water in green inland coconuts at different stages of maturity.

In conclusion, the biochemical profile of the coconut water from dwarf coconut palms planted in an inland region varied from the sixth to the ninth month of maturation, with reductions observed in the concentrations of potassium, calcium, magnesium, chloride and in osmolarity, from the sixth to the ninth month. The elevated concentration of potassium means that coconut water could possibly be used to replace that electrolyte. Daily consumption of coconut water may possibly prevent nutritional deficiencies of calcium and magnesium. When we compared coconut water with ORS, we observed that neither the concentrations of glucose, sodium, potassium and chloride, nor the osmolarity of the coconut water from inland palms met the WHO recommendations for ORS.

\section{References}

1. Aragão WM. A importância do coqueiro-anão verde. http:// www21.sede.embrapa.br/noticias/artigos/2000/artigo.200412-07.2461636373/mostra_artigo. Access: 20/06/2000.

2. Ferraz LGB, Fonseca MAC, Freitas EV. IPA responde. Coqueiro. www.ipa.br/RESP/resp42.htm. Access: 24/02/2003.

3. Eiseman B. Intravenous infusion of coconut water. AMA Arch Surg. 1954;68:167-78.

4. Campbell-Falck D, Thomas T, Falck TM, Tutuo N, Clem K. The intravenous use of coconut water. Am J Emerg Med. 2000;18: 108-11.

5. Pradera ES, Fernandez E, Calderin O. Coconut water. A clinical and experimental study. Am J Dis Child. 1942;64:977-95.

6. Kuberski T, Roberts A, Linehan B, Bryden RN, Teburae M. Coconut water as a rehydration fluid. N Z Med J. 1979;90:98-100.

7. Chavalittamrong B, Pidatcha $P$, Thavisri U. Electrolytes, sugar, calories, osmolarity and $\mathrm{pH}$ of beverages and coconut water. Southeast Asian J Trop Med Public Health. 1982;13:427-31.

8. Collares EF, Souza NM. Soluções alternativas para hidratação oral em pediatria: Composição de refrigerantes, de infusões e de água de coco. Rev Paul Pediatr. 1985;3:46-9.
9. Saat M, Singh R, Sirisinghe RG, Nawawi M. Rehydration after exercise with fresh young coconut water, carbohydrateelectrolyte beverage and plain water. J Physiol Anthropol Appl Human Sci. 2002;21:93-104.

10. Adams W, Bratt DE. Young coconut water for home rehydration in children with mild gastroenteritis. Trop Geogr Med. 1992;44: 149-53.

11. Fagundes Neto U, Franco L, Tabacow K, Machado NL. Negative findings for use of coconut water as an oral rehydration solution in childhood diarrhea. J Am Coll Nutr. 1993;12:190-3.

12. Msengi $A E$, Mbise RL, Msuya PM, Do Amsi DM. The biochemistry of water from unripe coconuts obtained from two localities in Tanzania. East Afr Med J. 1985;62:725-9.

13. Gonçalves RR, Miller O. Bioquímica do sangue: substâncias eletrolíticas. In: Gonçalves RR, Miller O. Laboratório para o clínico. $8^{a}$ ed. São Paulo: Atheneu; 1999.

14. Schales O, Schales SS. A simple and accurate method for determination of chloride in biological fluids. J Biol Chem. 1941; 140:879-84.

15. Westgard JO, Barry PL, Hunt MR, Groth T. A multi-rule shewhart chart of quality control in Clinical Chemistry. Clin Chem. 1981;27: 493-501.

16. Bergmeyer HU. Methods of enzymatic analysis. $3^{a}$ ed. Deerfield Beach: VCH; 1986.

17. Blaedel WJ, UhI JM. Nature of materials in serum that interfere in the glucose oxidase-peroxidase-0-dianisidine method for glucose, and their mode of action. Clin Chem. 1975;21:119-24.

18. Morin LG. Direct colorimetric determination of serum calcium with o-cresolphthalein complexon. Am J Clin Pathol. 1974;61: 114-7.

19. Mann $\mathrm{CK}$, Hoe JH. Spectrophotometric determination of magnesium with sodium 1-azo-2-hidroxy-3-(2,4dimethylcarboxanilido)-naphthalene-1-(2-hidroxybenzene-5sulfonate). Anal Chem. 1956;28:202-5.

20. Pennock CA, Passant LP, Bolton FG. Estimation of cerebrospinal fluid protein. J Clin Pathol. 1968;21:518-20.

21. Trevelyan WE, Procter DP, Harrison JS. Detection of sugar on paper chromatograms. Nature. 1950;166:444-5.

22. Conn EE, Stumpf PK. Métodos em bioquímica. In: Conn EE, Stumpf PK. Manual de bioquímica. $2^{a}$ ed. São Paulo: Universidade de São Paulo; 1972. p. 391-2.

23. Jandel Sigma Stat. Statistical software, 2.0. 1995.

24. Toporovski MS, Gutierrez MT, Padula AC, Jarolausky E, Gonsalves ES, Delgatto PF, et al. Diferenças nas concentrações de eletrólitos e açúcar no preparo do soro caseiro para hidratação oral (estudo de 50 amostras). In: Anais do VIII Congresso Brasileiro de Gastroenterologia Pediátrica; 1995 abril; Londrina, Brasil.

25. Sena LV, Maranhão HS, Morais MB. Avaliação do conhecimento de mães sobre terapia de reidratação oral e concentração de sódio em soluções sal-açúcar de preparo domiciliar. J Pediatr (Rio J). 2001;77:481-6.

26. World Health Organization. A Manual for the Treatment of Acute Diarrhoea for Use by Physicians and Other Senior Health Workers. WHO 1990. (WHO/CDD/SER80.2 Ver 2).

27. World Health Organization. Reduced osmolarity salts (ORS) formulation. New York: UNICEF; 2001. (WHO/FCH/CAH/0.1.22).

28. Institute of Medicine, Standing Committee on the Scientific Evaluation of Dietary Reference Intakes, Food and Nutrition Board. Dietary reference intakes for calcium, phosphorus, magnesium, vitamin D, and fluoride. Washington: National Academy Press; 1999. p. 432.

Correspondence:

Ulysses Fagundes-Neto

Rua Conselheiro Rodrigues Alves, 1247

CEP 04014-012 - São Paulo, SP - Brazil

Tel.: +55 (11) 5549.7699

Fax: +55 (11) 5576.4313

E-mail: ulyneto@osite.com.br 